\title{
Sistem Informasi Akuntansi: Penerimaan Kas di Lembaga Zakat, Infaq dan Shadaqah
}

\author{
Miftachul Hanifa, Fityan Izzah Noor
}

Universitas Muhammadiyah Sidoarjo, Indonesia

OPEN ACCESS

ISSN 2548-3501 (online)

Edited by:

Abdurrahman Maulana Yusuf ${ }^{*}$ Correspondence:

Fityan Izzah Noor

fityan_umsida@yahoo.co.id

Received: 9 September 2021

Accepted: 25 January 2022

Published: 31 January 2022

Citation:

Noor (2022) Sistem Informasi Akuntansi: Penerimaan Kas di Lembaga Zakat, Infaq, Shadaqah
The purpose of this research was to find out the application of accounting information systems at zakat, infaq, shadaqah institutions in an effort to improve internal control of cash receipts at LAZISMU Sidoarjo. In this research, the main focus is the Technology Acceptance Model (TAM), which was introduced by Davis in 1989, which is an adaptation of the Theory of Reasoned Action (TRA) which is a theory to model user acceptance of technology. This research approach used a qualitative approach with primary data sources. Data collection was obtained from interviews, observations and documentation. data validity techniques with triangulation models. The results of the study stated that the application of accounting information systems in LAZISMU Sidoarjo Regency has used a central system, namely ZISKA software stands for (Zakat, Infaq, Sadaqah, and Humanity). The advantages of the system are more detailed. However, there are obstacles that occur such as network disruptions and to prevent the risk of data loss data backup is performed. To anticipate any recording errors on cash receipts, cross-checks and evaluation are conducted through meetings. The use of forms or documents has been numbered printed. Transparent financial statements to the public. Cash deposits to the bank are done every day and directly deposited on bank working days. There are some weaknesses in the internal control element.

\section{Keywords: ZISKA, Accounting and Internal Control Information Systems}

Penelitian ini bertujuan untuk mengetahui penerapan sistem informasi akuntansi pada lembaga zakat, infaq, shadaqah dalam upaya peningkatan pengendalian internal pada penerimaan kas di LAZISMU Sidoarjo. Dalam penelitian ini, teori utamanya adalah Technology Acceptance Model (TAM), yang diperkenalkan oleh Davis pada tahun 1989 yaitu suatu adaptasi dari Theory of Reasoned Action (TRA) yang dikhususkan untuk memodelkan penerimaan pemakai (User acceptance) terhadap teknologi. Pendekatan penelitian ini menggunakan pendekatan kualitatif dengan sumber data primer. Pengumpulan data diperoleh pada hasil wawancara, observasi dan dokumentasi. Teknis keabsahan data dengan model triangulasi. Hasil penelitian menyatakan bahwa penerapan sistem informasi akuntansi di LAZISMU Kabupaten Sidoarjo telah menggunakan sistem dari sentral pusat yaitu software ZISKA singkatan dari (Zakat, Infaq, Shadaqah, dan Kemanusiaan). Kelebihan dari sistem tersebut lebih terperinci. Namun, terdapat kendala yang terjadi seperti gangguan jaringan dan untuk mencegah adanya risiko kehilangan data dilakukan backup data. Untuk mengantisipasi adanya kesalahan pencatatan pada penerimaan kas dilakukannya crossceck dan evaluasi melalui rapat. Penggunaan formulir atau dokumen telah bernomor urut tercetak. Laporan keuangan yang transparan kepada publik. Penyetoran kas ke bank dilakukan setiap hari dan langsung disetorkan di hari kerja bank. Pada unsur pengendalian internal ditemukan beberapa kelemahan. 


\section{PENDAHULUAN}

Perkembangan teknologi informasi yang semakin canggih, menjadikan pencatatan siklus akuntansi pada zaman dahulu yang masih menggunakan sistem manual telah bergeser menggunakan sistem komputer (elektronik) (Dewa Made Agung Putra Wiguna, 2016). Hal ini, mendorong manusia untuk dapat mempelajari dan menggunakannya. Teknologi informasi memberikan kemudahan-kemudahan dalam mengolah, mengelola serta menyajikan informasi keuangan adanya dukungan suatu sistem informasi (Sutra \& Prabawa, 2020b). "Sistem informasi akuntansi merupakan sistem yang memiliki tujuan untuk mengumpulkan, memproses data serta melaporkan informasi yang berhubungan dengan transaksi keuangan" (Dita \& Putra, 2016). Menurut (Puji Astuti \& Dharmadiaksa, 2014) bahwa "Sistem informasi akuntansi tidak hanya pengumpulan data, pengolahan, penyimpanan dan dokumentasi serta pelaporan untuk kepentingan internal dan eksternal perusahaan selain itu juga berfungsi sebagai pedoman sertsa pengendali terhadap bagaimana pendokumentasian tersebut harus dilakukan oleh suatu organisasi, baik itu organisasi berorientasi laba atau bukan."

Lembaga pengelola dana zakat, infaq dan shadaqah di Indonesia ada dua, yakni Badan Amil Zakat Nasional (BAZNAS) dan Lembaga Amil Zakat (LAZ) yang bertugas untuk mengelola, menyalurkan, dan mendayagunaan. LAZISMU ialah singkatan dari "Lembaga Amil Zakat, Infaq, dan Shadaqah Muhammadiyah, yang merupakan lembaga zakat tingkat nasional yang berkhidmat dalam pemberdayaan masyarakat melalui pendayagunaan secara produktif dana zakat, infaq, dan shadaqah, wakaf dan dana kederrmawanan lainnya baik perseorangan, lembaga, perusahaan dan instansi lainnya" (LAZISMU). Menurut (Chairina \& Wehartaty, 2019) zakat ialah kewajiban untuk mengeluarkan hartanya yang telah memenuhi persyaratan yang ditentukan oleh agama, untuk diberikan kepada orang-orang berhak menerima zakat yang termasuk ke dalam delapan golongan penerima zakat. Zakat juga tidak hanya bermanfaat untuk dirinya sendiri, zakat juga dapat dirasakan oleh orang lain.

Sedangkan infaq merupakan pengeluaran sebagian harta yang dilakukan seseorang secara sukarela, saat ia mendapatkan rizki, sebanyak yang ia kehendakinya (Sujadijaya, 2017). Selain zakat dan infaq bentuk lainnya yaitu shadaqah. Sedekah merupakan pemberian sesuatu yang bersifat kebaikan, baik berupa materi atau nonmateri kepada orang lain. Hal yang dilakukan oleh pemerintah yaitu dengan membentuk lembaga pengelola dana zakat, infaq, dan shadaqah untuk memaksimalkan pengelolaan dana zakat, infaq, dan shadaqah.

"Pertumbuhan Lembaga Amil Zakat (LAZ) dari tahun ke tahun menunjukkan kemajuan yang cukup signifikan, agar setiap lembaga pengelola zakat bekerja secara profesional, amanah, transparan, dan akuntabel perlu melakukan perbaikan di masa yang akan datang meski masih ada kendala dan kekurangan" (Hati, 2017). Salah satu aktivitas yang sering dilakukan ialah aktivitas yang berkaitan dengan penerimaan kas. Sistem informasi akuntansi penerimaan kas ialah bagian penting dalam siklus akuntansi yang digunakan sebagai sarana penunjang kegiatan operasional oleh suatu perusahaan. Sistem informasi akuntansi yang berbasis elektronik dapat mendorong lembaga amil zakat khususnya bagian keuangan dapat melakukan tugasnya dengan lebih mudah untuk memberikan informasi yang akurat yang dapat diakses oleh pihak internal maupun eksternal, yang berkaitan dengan Lembaga Amil Zakat, Infaq, serta Shadaqah (LAZIS). "Pihak internal merupakan manajemen LAZIS bahwa informasi akuntansi digunakan untuk memenuhi keperluan dalam perencanaan, pengkoordinasian, pengarahan, penilaian kinerja internal serta pengendalian terhadap kegiatan organisasi. Sebaliknya pihak eksternal merupakan muzakki, mustahik, pemerintah, masyarakat umum serta pihak lain. Yang paling utama dari pihak eksternal yaitu muzakki, mereka merupakan pihak yang sangat berkepentingan dengan hasil dari informasi akuntansi sebab berhubungan dengan informasi pertanggungjawaban keuangan ataupun dana Zakat, Infaq, serta Shadaqah (ZIS) yang sudah diamanatkan pada suatu LAZIS" (Fauziah, 2018).

Pengendalian internal adalah sistem dan mekanisme yang dipatuhi bersama meliputi struktur organisasi bertujuan untuk menjaga seluruh kekayaan atau asset organisasi (Aminah, 2016). Untuk mendukung dari proses pengendalian tersebut agar berjalan secara efektif, harus memiliki unsur pokok sistem pengendalian. Unsur pokok sistem pengendalian internal yang dikemukakan oleh (Sutra \& Prabawa, 2020a) yaitu: 1) struktur organisasi, 2) sistem wewenang dan prosedur pencatatan organisasi, 3) pelaksanaan kerja secara sehat, 4) pegawai berkualitas. "Tujuan dari adanya sistem pengendalian internal tersebut ialah untuk menjaga kekayaan organisasi, untuk menjaga keakuratan laporan keuangan perusahaan, untuk menjaga kelancaran operasi perusahaan, untuk menjaga kedisiplinan dipatuhinya kebijakan manajemen, dan agar semua lapisan yang ada di perusahaan tunduk pada hukum dan aturan yang sudah ditetapkan di perusahaan" (Anto, Tamburaka, \& Abbas, 2020).

Seperti penelitian terdahulu yang telah dilakukan oleh Bashori (2015) pada BAZ di Jawa Timur bahwa "Penerapan sistem informasi akuntansi ZIS tidak menggunakan SIA secara baik dan benar, sistem yang digunakan masih belum efektif dan efisien karena tidak menggunakan program yang telah diberikan oleh BAZNAS pusat dalam pemrosesan transaksi. Selain itu, penomoran kwitansi bukti penerimaan dana ZIS tidak menggunakan penomoran permanen serta pengendalian internal masih mengacu pada laporan pertanggungjawaban dari pelaksana harian atau pegawai BAZ sehingga berakibat pada kinerja organisasi."

Sementara penelitian yang dilakukan oleh (Astuti \& Dharmadiaksa, 2014) pada LAZIS Jateng cabang Solo menunjukkan bahwa "Sistem informasi akuntansi di LAZIS Jateng cabang Solo diproses menggunakan sistem Silazisku. Adanya sistem Silazisku membuat bagian keuangan dapat melakukan pekerjaannya dengan mudah. Dengan menginput data dan informasi dalam sistem silazisku pengolahan akan secara otomatis dilakukan oleh sistem dan menghasilkan output berupa laporan keuangan yang menyajikan data dan informasi keuangan, sehingga bagian keuangan tidak perlu melakukan pengolahan data dengan melakukan perhitungan satu per satu secara manual untuk membuat laporan yang menyajikan data dan informasi keuangan. Ini menunjukkan sistem Silazisku dapat meningkatkan efisiensi dalam bekerja."

Novelty dalam penelitian ini menambahkan obyek yang diteliti pada pengendalian internal pada penerimaan kas dan menggunakan sistem informasi dari sentral yaitu software Ziska. Tujuan penelitian ini yaitu untuk mengetahui Sistem Informasi Akuntansi Pada Lembaga Zakat, Infaq, Shadaqah 
Dalam Upaya Peningkatan Pengendalian Internal Pada Penerimaan Kas.

\section{METODE}

\section{Pendekatan Penelitian}

Pendekatan penelitian yang digunakan dalam penelitian ini adalah pendekatan kualitatif. Menurut (Dr. Wahidmurni, 2017) menyatakan bahwa pendekatakan kualitatif adalah suatu proses penelitian dan pemahaman yang didasarkan pada metodologi yang menyelidiki suatu fenomena sosial dan masalah manusia. Dalam melakukan penelitian, seorang. peneliti membutuhkan adanya suatu metode, cara atau taktik. sebagai langkah untuk memecahkan suatu permasalahan dengan tujuan yang diharapkan. Metode penelitian ini menggunakan penelitian kualitatif. Metode penelitian pada dasarnya merupakan cara ilmiah untuk mendapatkan data dengan tujuan dan kegunaan tertentu (Sugiyono, 2016). Dengan metode tersebut, peneliti mempunyai tujuan untuk mengumpulkan data serta mengamati secara seksama yang berhubungan dengan adanya masalah yang sedang diteliti agar memperoleh data yang valid, berguna dalam mendukung penyusunan dalam laporan penelitian.

\section{Fokus Penelitian}

Adapun fokus penelitian dalam penelitian ini berguna untuk memberikan arahan dalam gambaran yang sejalan dengan permasalahan dan tujuan penelitian. Hal ini dilakukan untuk menghindari pembahasan yang luas. Selain itu terdapat keterbatasan baik dari tenaga, dana, dan waktu di masa pandemi saat ini. Maka penelitian ini berfokus menganalisa penerapan sistem informasi akuntansi tentang aktivitas penerimaan kas bukan termasuk penerimaan berupa barang yang termasuk dalam penerimaan ZIS dalam upaya peningkatan pengendalian internal di LAZISMU Kabupaten Sidoarjo. Pengendalian tersebut berguna untuk mengawasi setiap aktivitas yang dilakukan, apakah telah diotorisasi dengan benar dan jelas dimana segala kejadian tersebut tidak direkayasa dan benarbenar terjadi.

\section{Rancangan Penelitian}

Prosedur rancangan penelitian ini adalah sebagai berikut:

a. Sebelum memulai dilakukan penentuan judul dan objek yang akan diteliti.

b. Teknik pengumpulan data yang yang digunakan dalam penelitian ini dengan menggunakan wawancara yang dilakukan di objek penelitian, melakukan observasi dan dokumentasi sebagai pelengkap dari penggunaan metode wawancara maupun observasi.

c. Menguji keabsahan dengan menggunakan triangulasi yakni triangulasi sumber dan teknik.

d. Melakukan analisis data dari mulai reduksi data hingga memverifikasi data yang didapat selama penelitian

e. Menganalisis data penerapan sistem informasi akuntansi pada dalam upaya peningkatan pengendalian internal pada penerimaan kas menurut teori dan jurnal-jurnal dari penelitian sebelumnya dengan membandingkan hasil data yang ada pada LAZISMU Sidoarjo.

f. Menarik kesimpulan dan saran dari seluruh hasil data yang telah diteliti dan dianalisis.

\section{Lokasi Penelitian}

Lokasi penelitian ini pada Lembaga Zakat, Infaq, Shadaqah Muhammadiyah (LAZISMU) Kabupaten Sidoarjo. Lembaga tersebut berbentuk non profit, beralamat di Kantor PDM Sidoarjo Lt.2 Jalan Mojopahit 666-B Sidoarjo.

\section{Jenis Data dan Sumber Data}

Jenis data yaitu data kualitatif, merupakan data yang berupa rangkaian kalimat tidak dapat diukur melalui skala numerik (Sugiyono, 2015).

\section{Sumber Data}

Sumber data dari penelitian adalah sumber data primer. Menurut (Sekaran \& Bogie, 2017), data primer lebih mengarah pada informasi yang diperoleh secara langsung dari informan yang terkait dengan tema dan fokus penelitian untuk memperoleh tujuan tertentu dari suatu penelitian. Data tersebut, dapat berupa dokumen atau catatan akuntansi yang digunakan pada proses sistem informasi akuntansi penerimaan kas pada lembaga zakat, infaq, dan shadaqah.

\section{Teknik Pengumpulan Data}

Teknik pengumpulan data yang digunakan dalam penelitian ini adalah:

\section{Wawancara}

Wawancara ialah pertemuan dua orang melalui tanya jawab untuk bertukar informasi dan ide, sehingga dapat dikontruksikan makna dalam suatu topik tertentu (Lexy J. Moleong, 2019). Wawancara ini dilakukan dengan informan yang berkaitan dengan sistem informasi akuntansi penerimaan kas pada bagian administrasi dan perkantoran, petugas jungut/relawan (pengumpul dana ZIS), dan juga muzakki/donatur yang bertujuan untuk memperoleh data maupun informasi yang dapat membantu dalam penelitian ini.

\section{Observasi}

Observasi merupakan suatu prosess yang kompleks, suatu proses biologis dan psikologis. Dua diantara yang terpenting adalah proses-proses pengamatan dan ingatan (Rijali, 2019). Observasi dilakukan untuk mengamati proses berjalannya kegiatan transaksi dalam aktivitas penerimaan kas yang berguna untuk mengetahui fenomena dari penerapan sistem informasi akuntansi dalam upaya peningkatan pengendalian internal penerimaan kas di LAZISMU Sidoarjo.

\section{Dokumentasi}

Dokumentasi ialah catatan peristiwa yang sudah berlalu yang berbentuk tulisan, gambar, atau karya-karya monumental dari seorang (Gunawan, 2014). Aktivitas yang dilakukan yaitu dengan mengumpulkan data dari dokumen dan arsip perusahaan mengenai penerimaan kas. Dokumentasi tersebut merupakan pelengkap dari penggunaan metode wawancara dan pengamatan atau observasi dalam penelitian kualitatif.

\section{Uji Keabsahan Data}

Menurut (Suwarsono, 2016), upaya yang dilakukan peneliti dalam memeriksa keabsahan data merupakan cara yang dilakukan oleh peneliti dalam menanggulangi kegalauan mengenai keabsahan data dalam penelitian kualitatif. Terdapat standar dalam menguji keabsahan data untuk menjamin data. teknik pemeriksaan keabsahan data terbagi menjadi tujuh yaitu perpanjangan keikut-sertaan, ketekunan pengamatan, triangulasi, pengecekan sejawat, kecukupan referensial, kajian 
kasus negatif dan pengecekan anggota

Penelitian ini menggunakan teknik keabsahan data dengan model triangulasi. Triangulasi adalah suatu teknik keabsahan data yang memanfaatkan sesuatu yang lain guna untuk mendukung penelitian. Hal ini dilakukan untuk membandingkan dengan data yang telah diperoleh. Dalam penelitian ini terdapat dua triangulasi yaitu:

\section{Triangulasi sumber}

Penelitian ini menggunakan teknik triangulasi dengan sumber. Teknik triangulasi dengan sumber berarti mengecek kembali dan membandingkan informasi yang telah diperoleh dengan waktu dan alat yang berbeda. cara mengecek dengan menggunakan teknik triangulasi sumber yaitu: membandingkan data yang diamati dengan hasil pengamatan dan hasil wawancara, membandingan hasil wawancara satu orang dengan orang lain, membandingkan pendapat satu orang dengan masyarakat lain, dan membandingkan hasil wawancara dengan dokumen yang terkait.

\section{Triangulasi teknik}

Triangulasi teknik dengan menggunakan teknik pengumpulan data yang berbeda-beda untuk mendapatkan data dari sumber yang sama. Triangulasi teknik ini bertujuan untuk mengecek derajat kepercayaan penemuan hasil penelitian dengan cara pengecekan informasi yang di dapat dari wawancara sama dengan observasi, hasil wawancara dan observasi dengan dokumentasi.

\section{Teknik Analisis}

Analisis data dalam penelitian kualitatif, biasanya dilakukan ketika pengumpulan data berlangsung maupun setelah selesai pengumpulan data dalam periode tertentu. Pada saat wawancara, peneliti sebelumnya telah menganalisis jawaban yang diwawancarai . Pertanyaan akan terus berlanjut sampai mendapatkan data kredibel. Menurut Sugiyono, aktivitas yang dilakukan dalam analisis data kualitatif adalah secara interaktif dan berlangsung secara terus menerus sampai diperoleh data yang memuaskan dan tuntas. Hal ini dilakukan sampai datanya jenuh.

Aktivitas dalam analisis data, yaitu: reduksi data, data display (penyajian data), dan kesimpulan dan verifikasi. Reduksi data dalam penelitian ini adalah mengumpulkan data dan informasi untuk mengetahaui penerapan sistem informasi akuntansi dalam upaya peningkatan pengendalian pada penerimaan kas. Setelah data direduksi, langkah berikutnya yaitu data display (penyajian data). Dalam penelitian kualitatif, data display (penyajian data) dapat berupa uraian singkat, bagan, hubungan antar kategori, flowchart dan sejenisnya. Dalam hal ini penyajian data berguna dalam memahami apa yang terjadi. Dengan demikian, langkah selanjutnya adalah penarikan kesimpulan dan verifikasi.

\section{HASIL DAN PEMBAHASAN}

\section{[ Table 1 about here.]}

\section{Sistem Informasi Akuntansi}

Sistem informasi akuntansi merupakan sistem yang memiliki peranan penting bertujuan untuk mengumpulkan dan memproses data serta melaporkan informasi yang berhubungan dengan transaksi keuangan. Dalam hal ini peneliti melakukan wawancara dengan Ibu Heny bagian manager administrasi dan perkantoran, Ibu Heny menyatakan bahwa:

"Dalam menyajikan laporan keuangan menggunakan sistem dari sentral pusat yang menggunakan software ZISKA singkatan dari (Zakat Infaq Shadaqah dan Kemanusiaan). Sistem tersebut sederhana jadi kita yang mengolah langsung kemudian dimasukkan ke sistem."

Untuk mendukung wawancara diatas, maka peneliti melakukan wawancara dan observasi pada bagian staff administrasi dan perkantoran dengan Ibu Pratiwi yang merupakan khusus bagian penerimaan kas di LAZISMU Sidoarjo beliau menyatakan bahwa:

"Sistem informasi akuntansi penerapannya sudah menggunakan sistem. Aplikasi dari pusat yang bernama ZISKA yang merupakan sistem berbasis excel. Kelebihan dari sistem tersebut lebih terperinci dalam pencatatan dan memudahkan pekerjaan bagian administrasi perkantoran dalam memproses data dan informasi di bidang keuangan. Namun, ada kendala yang terjadi seperti gangguan jaringan dan untuk mencegah adanya risiko kehilangan data tersebut dilakukan backup data."

Jadi, dalam mengolah data menjadi sebuah informasi LAZISMU Sidoarjo menggunakan software ZISKA untuk memudahkan pekerjaan di bidang keuangan.

\section{Sistem Penerimaan Kas}

LAZISMU Sidoarjo ialah lembaga nirlaba yang menangani dana zakat, infaq, dan shadaqah. Penerimaan kas di LAZISMU Sidoarjo berasal dari tiga sumber

kegiatan yaitu penerimaan kas secara langsung, penerimaan kas melalui transfer, dan penerimaan kas melalui penjemputan zakat. Hal ini dibuktikan melalui hasil wawancara dengan Ibu Heny, beliau menyatakan bahwa:

"Tidak mempersulit muzakki/donatur dalam membayarkan rezekinya. Jadi ada tiga cara bisa langsung datang kesini, transfer, bisa diambil oleh petugas jungut."

Untuk mengetahui proses prosedur dari penerimaan kas yang diterapkan oleh LAZISMU Sidoaarjo, maka peneliti melakukan wawancara dan observasi lebih lanjut dengan informan yang berhubungan pada penerimaan kas untuk mendukung adanya wawancara sebelumnya.

\section{Penerimaan kas secara langsung}

Informan yang berhubungan langsung dengan penerimaan kas yaitu Ibu Pratiwi, beliau menyatakan bahwa:

"Prosedur dari penerimaan kas secara langsung dimulai dari muzakki/donatur yang datang langsung ke kantor hanya menyebutkan nama dan nominal untuk muzakki/donatur tetap. Kemudian bagian administrasi akan mencari nama donatur di komputer dengan sistem yang digunakan untuk penginputan data. Setelah itu, data yang diinput kemudian diprint berupa kwitansi. Kwitansi dicetak menjadi dua bagian, yaitu satu lembar berwarna putih untuk donatur dan satu lembar berwarna merah atau kuning untuk administrasi sebagai arsip."

Dalam hal ini peneliti juga melakukan wawancara dengan Ibu 
Adnes yang merupakan salah satu donatur tetap di LAZISMU, Sidoarjo beliau menyatakan:

"Saya pembayaran melalui cash atau secara langsung. Jadi saya membayarkan uang saya untuk infaq bulanan secara langsung kemudian saya memberitahukan ke Ibu Pratiwi nama dan nominal yang dibayarkan. Kemudian saya mendapatkan bukti berupa kwitansi."

\section{Penerimaan Kas Melalui Transfer}

Penerimaan kas melalui transfer ini memudahkan muzakki/donatur yang tidak bisa mendatangi kantor di masa pandemi saat ini. Maka dalam hal ini, peneliti melakukan wawancara dengan Ibu Pratiwi, beliau menyatakan bahwa:

"Pembayaran melalui transfer bank dapat dilakukan dengan cara muzakki/donatur membayarkan sejumlah uangnya untuk zakat, infaq, dan shadaqah dengan mentransferkan ke nomor rekening LAZISMU Sidoarjo. Untuk transfer bank, nomor rekening zakat yang digunakan berbeda dengan nomor rekening infaq atau shadaqah. Pemisahan ini untuk mempermudah dalam proses pencatatan. Jika muzakki/donatur telah transfer, kemudian melakukan konfirmasi melalui whatsapp dengan menunjukkan bukti transfer kepada pihak LAZISMU Sidoarjo. Setelah muzakki/donatur konfirmasi, bagian administasi melakukan pengecekan ke rekening bank dan menginput data muzakki/donatur. "

Jika ada muzakki/donatur yang tidak menyebutkan nama setelah transfer kepada LAZISMU Sidoarjo, bagian administrasi melakukan pengecekan pada rekening koran akan tetapi jika tidak bisa dilacak nama si pengirim atau donator, maka diberi nama hamba Allah ke laporan.

\section{Penerimaan Kas Melalui Penjemputan Zakat}

Dalam hal ini, peneliti melakukan wawancara dengan Ibu Pratiwi, beliau menyatakan bahwa:

"Petugas jungut pada saat mendatangi rumah muzakki/donatur sudah membawa kwitansi dan majalah. Setelah donatur melakukan pembayaran diberikan kwitansi asli berwarna putih dan yang kwitansi (copy) berwarna merah atau kuning dibawa petugas jungut. Kemudian petugas jungut datang ke kantor untuk menyerahkan kwitansi masing-masing nama donatur dan sejumlah uang yang diterima. Dan petugas jungut menyetorkan ke bagian administrasi paling lambat tanggal 25 setiap bulan. Kemudian uang yang disetorkan petugas jungut ke bagian administrasi disetorkan ke bank langsung di hari kerja bank. Atau bisa juga petugas jungut hanya menyerahkan slip setoran bank sama kwitansi masing-masing nama donatur ke bagian administrasi."

Untuk mendukung wawancara diatas, maka peneliti melakukan wawancara dengan Ibu Sri yang merupakan petugas pengumpul dana ZIS atau petugas jungut di LAZISMU Sidoarjo beliau menyatakan bahwa:

"Jemput ke rumah-rumah. Melihat kesiapan donatur masing-masing. Ada yang minta di awal bulan, setiap tanggal 10 ataupun di akhir bulan. Mengikuti kesepakatan dengan donatur. Kemudian disetorkan ke bank lalu slip setoran bank disetorkan ke bagian staff administrasi disertai kwitansi masing-masing nama donatur. Dan ada kendala seperti, jarak antara rumah kita dengan rumah donatur, rumah yang didatangi kosong jika tidak ada komunikasi sebelumnya, apalagi saat masa pandemi saat ini, sering tidak bertemu dan mereka banyak yang berkurang rejekinya sehingga ada donatur yang berhenti sementara di masa pandemi saat ini."

Berdasarkan hasil wawancara diatas dan observasi yang dilakukan oleh peneliti dengan Ibu Pratiwi, maka bagian yang terlibat dengan penerimaan kas yaitu:

\section{Bagian administrasi (Penerimaan Kas)}

Bagian administrasi (penerimaan) bertugas serangkaian proses penerimaan dana ZIS dari muzakki/donatur, membuat bukti penerimaan kas berupa kwitansi, melakukan pencatatan yang berkaitan dengan penerimaan menggunakan sistem aplikasi, menyimpan bukti setoran bank.

\section{Petugas jungut/relawan}

Petugas jungut bertanggungjawab pada pengumpulan dana ZIS dari muzakki/donatur, menyerahkan bukti penerimaan kas berupa kwitansi, bukti setoran bank dan kas fisik kepada bagian administrasi (penerimaan).

Berdasarkan hasil wawancara dan dokumentasi dengan Ibu Pratiwi adapun dokumen transaksi yang digunakan dalam sistem penerimaan kas sebagai berikut:

\section{Kwitansi,}

file dokumen bukti transaksi penerimaan dana ZIS yang tercetak rangkap dua dimana kwitansi asli berwarna putih untuk muzakki/donatur sedangkan kwitansi copy berwarna merah atau kuning untuk LAZISMU Sidoarjo sebagai arsip.

\section{Formulir calon muzakki/donatur tetap,}

Formulir ini diberikan kepada calon muzakki/donatur yang ingin bersedia bergabung menjadi muzakki/donatur tetap di LAZISMU Sidoarjo.

\section{Bukti transfer}

file bukti transfer yang diberikan oleh muzakki/donatur yang telah membayar melalui transfer pada nomor rekening LAZISMU Sidoarjo.

\section{Rekening koran bank,}

rekening ini digunakan untuk mengetahui informasi mengenai kas masuk dan keluar di LAZISMU Sidoarjo.

Berdasarkan hasil wawancara dengan Ibu Pratiwi adapun catatan akuntansi yang digunakan dalam sistem penerimaan kas yaitu jurnal umum, jurnal penerimaan kas, rekapitulasi laporan penerimaan dana (laporan kas harian), buku besar, dan buku pembantu.

\section{Flowchart Sistem Informasi Akuntansi Penerimaan Kas}

Bagan alir (flowchart) berguna untuk menjelaskan gambaran prosedur pemrosesan transaksi dan arus data melalui sistem. Berikut ini adalah flowchart penerimaan dana ZIS (Zakat, Infaq, dan Shadaqah): 
Muzakki/donatur datang langsung ke kantor LAZISMU Kabupaten Sidoarjo.

(1) Prosedur penerimaan kas dimulai dari muzakki/donatur yang menyetorkan sejumlah uang atau rezekinya ke bagian administrasi. (2) Bagian administrasi menerima uang dari muzakki/donatur. Kemudian mengisi data disistem dan mencetak kwitansi dua rangkap. Setelah tercetak ditanda tangani oleh administrasi kemudian kwitansi tersebut diberikan kepada muzakki/donatur tetap untuk ditanda tangani muzakki/donatur. (3) Setelah ditanda tangani muzakki/donatur dua kwitansi tersebut diberikan ke bagian administrasi. Untuk kwitansi berwana putih (asli) diberikan kepada muzakki/donatur sedangkan kwitansi yang berwarna merah atau kuning (copy) disimpan sebagai arsip oleh bagian administrasi. (4) Bagian administrasi membuat laporan penerimaan kas dan mencatatnya ke dalam jurnal penerimaan kas. (5) Setelah uang terkumpul di bagian administrasi kemudian uang tersebut disetor langsung pada bank dan diporoses. Bagian administrasi menerima laporan memo kredit/rekening koran bank untuk disimpan. (6) Prosedur penerimaan kas antara muzakki/donatur tetap, muzakki/donatur isidentil dan pelunasan piutang sama, dan yang membedakan pada calon donatur tetap hanya pengisian formulir pada calon muzakki/donatur dan sama-sama mendapatkan kwitansi sebagai bukti pembayaran.

\section{Muzakki/donatur melakukan transfer ke rekening LAZISMU Kabupaten Sidoarjo.}

(1) Prosedur penerimaan kas dimulai dari muzakki/donatur yang mentrasfer sejumlah uang atau rezekinya ke nomor rekening LAZISMU Kabupaten Sidoarjo. (2) Selanjutnya muzakki/donatur melakukan konfirmasi transfer kepada bagian administrasi dengan memberikan bukti transfer. (3) Bagian administrasi menerima konfirmasi dan bukti transfer dari muzakki/donatur setelah itu melakukan cek saldo bank dan menginput data muzakki/donatur. (5) Kemudian bagian administrasi membuat laporan penerimaan kas dan mencatatnya ke dalam jurnal penerimaan kas.

\section{Muzakki/donatur melakukan pembayaran kepada petugas jungut atau pengumpul dana ZIS LAZISMU Kabupaten Sidoarjo.}

Prosedur penerimaan kas dimulai dari petugas jungut mendatangi rumah masing-masing muzakki/donatur. (1) Selanjutnya muzakki/donatur menyetorkan sejumlah uang atau rezekinya ke petugas jungut. (2) Petugas jungut menerima uang dari muzakki/donatur kemudian memberikan kwitansi dua rangkap yang telah ditanda tangani oleh petugas jungut untuk diberikan kepada muzakki/donatur dan ditanda tangani lalu diserahkan kembali kepada petugas jungut. Pada kwitansi berwarna putih (asli) diberikan kepada muzakki/donatur sebagai bukti penyetoran uangnya dan memberikan majalah untuk laporan keuangan. Sedangkan kwitansi berwarna merah atau kuning (copy) disimpan oleh petugas jungut. (3) Setelah uang terkumpul dan dihitung oleh petugas jungut, kemudian uang tersebut disetor langsung pada bank. Dan bank memperoses transaksi dan petugas jungut menyimpan slip bukti setoran bank. (4) Petugas jungut datang ke kantor untuk menyerahkan slip bukti setoran bank dan disertai kwitansi masing-masing nama donatur pada bagian administrasi. (5) Bagian administrasi menerima bukti setoran bank dan disertai kwitansi masing-masing nama donatur dari petugas jungut dan penginput data melalui sistem. (6) Kemudian membuat laporan penerimaan kas dan mencatatnya ke dalam jurnal penerimaan kas. (7) Bukti setoran bank dan disertai kwitansi masing-masing nama donatur dari petugas jungut disimpan oleh bagian administrasi sebagai arsip.

\section{Pengendalian Internal Pada Penerimaan Kas}

Unsur-unsur pokok sistem pengendalian Internal pada penerimaan kas dapat dilihat dari:

Adanya struktur organisasi. Melalui hasil wawancara dan observasi dengan Ibu Heny manager administrasi dan perkantoran, beliau menyatakan bahwa:

"Sebenarnya ada tiga manajer yaitu manajer fundrasing, manajer pentasyarufan, manajer keuangan dan ketatausahaan. Berhubung di bagian fundrasing itu kosong memang jadi tinggal dua manajer. Disamping itu dibantu sama staff keuangan dan staff publikasi. Staff keuangan itu membawahi para petugas jungut."

Selain itu juga berdasarkan hasil wawancara dengan petugas jungut/relawan:

"Ini sebenarnya bagian marketing. Bagian jungut membantu marketing saja dengan pendekatan waktu pengajian, atau saat ada acara seperti bazar dan parenting sekolah-sekolah kita diterjunkan ke acara itu."

Berdasarkan hasil wawancara dan observasi diatas, bahwa struktur organisasi LAZISMU Sidoarjo ada bagian yang tidak terisi atau kosong sehingga ada fungsi atau bagian lain bertugas merangkap.

\section{Sistem wewenang dan prosedur pencatatan dalam organisasi}

Berdasarkan hasil observasi yang dilakukan peneliti struktur organasasi tertempel di ruangan dan setiap fungsi atau bagian memiliki tugas pokok masing-masing. Prosedur pencatatan pada kas dibagi menjadi dua bagian yaitu bagian penerimaan dan bagian pengeluaran kas. Hal ini dibuktikan dengan hasil wawancara dengan Ibu Heny manager administrasi dan perkantoran, beliau menyatakan bahwa:

"Bagian penerimaan kas Mbak Tiwi. Kalau saya semua operasional pengeluaran dan setiap bulan itu saya seperti pentasyarufan juga kas operasional kecil juga saya dan jurnal hariannya mutasi kas."

Untuk mendukung wawancara diatas, maka peneliti melakukan wawancara dan observasi dengan Ibu Pratiwi sebagai staff administrasi dan perkantoran khususnya penerimaan kas, beliau menyatakan bahwa:

"Pada prosedur pencatatan di bukti kwitansi penerimaan kas. Kwitansi yang asli ada stempel dan tanda tangan sedangkan yang copy hanya tanda tangan saja."

Namun pada hasil wawancara dengan Ibu Heny adanya ketidaktelitian dari petugas seperti lupa memberikan stampel pada kwitansi pembayaran sehingga muzakki/donatur ada yang komplain.

"Namanya muzakki kan pribadinya sendiri-sendiri ya. 
Seumpamanya tidak ada stampel diprotes dengan forum pertemuan sekali 2 minggu itu biasanya menyampaikan nanti kita yang memberikan solusi."

Jadi, dalam hal ini sistem wewenang dan prosedur pencatatan di LAZISMU Sidoarjo diberikan kepada pihak yang memiliki tanggungjawab memberi otorisasi pada dokumen dengan adanya bukti yang sah.

\section{Pelaksanaan kerja yang sehat}

Dalam hal ini unsur kehati-hatian penting dijaga dalam melaksanakan berbagai tugas yang telah diberikan untuk menghindari kecurangan: Pemisahan tugas agar tidak seorang pun menangani transaksi di awal sampai akhir sendirian. Berikut hasil wawancara dengan Ibu Pratiwi, beliau menyatakan bahwa:

"Tidak ada. Saya sendiri pada bagian administrasi khususnya penerimaan kas."

Selain itu juga berdasarkan hasil wawancara dengan Ibu Sri sebagai petugas jungut/relawan:

"Setiap jungut ada wilayah masing-masing. Dan melihat banyaknya donatur kalau kuantitas donatur sedikit beberapa kecamatan diambil satu jungut. Bagian administrasi sudah membagi petugas jungut masing-masing wilayah, dan setiap donatur punya tanggung jawab sesuai wilayah yang dipegang."

Formulir atau dokumen bernomor urut cetak. Berikut adalah hasil wawancara dan observasi dengan Ibu Pratiwi, beliau menyatakan bahwa:

"Pada bagian atas pada kwitansi ini terdapat nomor registrasi mbak. Nah dimana dua digit angka dari depan menunjukkan kode petugas jungut, tiga angka berikutnya adalah kode wilayah Jawa Timur, dua angka lagi kode daerah kabupaten Sidoarjo, satu angka menunjukkan tingkat daerah dan sisa angka selanjutnya adalah nomor induk donatur. Penomoran ini sesuai di pedoman dari LAZISMU pusat."

Laporan keuangan yang transparan kepada publik. Berikut adalah hasil wawancara dengan Ibu Heny, beliau menyatakan bahwa:

“....Dan setiap bulan kita adakan majalah untuk diberikan kepada muzakki/donatur yang didalamnya berupa laporan keuangan jadi kita transparan ke muzakki/donatur tetap sehingga muzakki/donatur dapat mengetahui saldo kita berapa pemasukan dan pengeluaran kita berapa. Selama ini hanya di publikasikan majalah saja laporan keuangannya."

Untuk mendukung wawancara diatas, maka peneliti melakukan wawancara dengan Ibu Adanes salah satu donatur tetap di LAZISMU Kabupaten Sidoarjo, beliau menyatakan bahwa:

"Pertama, jelas penyalurannya selalu dapat rekap tiap bulan di majalah. Kemudian rekap laporan keuangan bulanannya selalu ada. Transparan antara pekerja dari LAZISMU kepada donatur."

Penyetoran kas ke bank dilakukan setiap hari dan langsung disetorkan di hari kerja bank. Berikut berdasarkan hasil wawancara dengan Ibu Pratiwi, beliau menyatakan bahwa:
"Setiap hari langsung disetor di hari kerja bank."

Dikarenakan pada petugas jungut juga terkait pada bagian penerimaan kas, maka peneliti juga melakukan wawancara dengan Ibu Sri, beliau menyatakan bahwa:

"Setelah menjemput dana ZIS uang tersebut disetorkan setiap hari kerja bank."

Dalam mengantisipasi adanya kesalahan pencatatan penerimaan kas dilakukan crossceck dan evaluasi melalui rapat. Berdasarkan hasil wawancara dengan Ibu Heny, beliau menyatakan bahwa:

“......Nah kita biasanya satu bulan sekali itu mengadakan rapat khusus petugas jungut, di luar rapat sama pengurus hanya kalangan petugas jungut dan staff kita selain pengurus. Satu bulan sekali tiap 2 minggu sekali kita mengadakan rapat. Lalu mbak tiwi biasanya mendata para donatur setiap bulan nah dari situ kita akan mengetahui. Nah kita biasanya mengumpulkan petugas jungut untuk mengevaluasi. Contohnya ini kok merah-merah kenapa orangnya? biasanya para petugas jungut akan cerita”

Selain itu juga berdasarkan hasil wawancara dengan petugas jungut/relawan dengan Ibu Sri, beliau menyatakan bahwa:

"Kesalahan pencatatan pernah terjadi, seperti kesalahan penulisan nama pada kwitansi seperti nama yang tidak tercantum. Apabila ada sisa tetap disetorkan atau lupa nama diberi nama hamba Allah karena uang tersebut bukan hak kita. Biasanya akan diprint kan oleh bagian staff administrasi siapa yang belum setor dan sama-sama mengingat apakah ada kwitansi yang belum disetorkan dari kwitansi akan diketahui apakah sudah bayar atau belum."

Dari hasil wawancara kedua informan tersebut, maka peneliti juga melakukan wawancara dengan Ibu Pratiwi yang berhubungan langsung pada penerimaan kas, beliau menyatakan bahwa:

"Kesalahan pencatatan pernah terjadi. Misalnya jumlah setoran di kwitansi totalnya Rp 500.000,- kemudian uang yang disetorkan ke bank oleh petugas jungut sebesar $R p$ 475.000,- bagian administrasi akan melakukan crossceck ke petugas jungutnya. Petugas jungut mengecek di buku catatannya. Terkadang donatur sudah bayar akan tetapi belum dicatat dibukunya. Kalau ada kekurangan seperti itu petugas jungut yang bertanggungjawab untuk menggantinya."

Jadi, dalam hal ini pelaksanaan kerja yang sehat di LAZISMU dapat diketahui dari beberapa faktor seperti pemisahan tugas agar suatu transaksi tidak boleh ditangani oleh satu fungsi atau satu orang saja, Selain itu penggunaan formulir atau dokumen bernomor urut cetak, laporan keuangan yang transparan kepada publik, penyetoran kas ke bank dilakukan setiap hari dan langsung disetorkan di hari kerja bank, dan dalam mengantisipasi adanya kesalahan pencatatan penerimaan kas dilakukan crossceck dan evaluasi melalui rapat

Pegawai berkualitas.

Salah satu unsur penggerak organisasi ialah sumber daya manusia. Dalam hal ini peneliti melakukan wawancara dengan Ibu Pratiwi karena beliau yang menjalankan sistem tersebut 
sehingga berdasarkan hasil wawancara tersebut dikatakan bahwa:

"Dalam mengoperasikan sistem dibutuhkan keahlian dibidangnya dan untuk meningkatkan kompetensi sumber daya manusia di bagian keuangan diperlukan pelatihan pada penggunaan sistem ZISKA.”

Sistem informasi akuntansi merupakan sistem yang memiliki tujuan untuk mengumpulkan, memproses data serta melaporkan informasi yang berhubungan dengan transaksi keuangan. Sistem informasi akuntansi pada lembaga zakat, infaq, dan shadaqah dalam upaya pengendalian internal pada penerimaan kas di LAZISMU Sidoarjo dari hasil penelitian yang diuraikan diatas telah menerapkan sistem yang digunakan pada sentral pusat yaitu software ZISKA yang merupakan sistem berbasis excel untuk memudahkan pekerjaan di bidang keuangan. Hal ini didukung oleh penelitian sebelumnya bahwa adanya perkembangan teknologi informasi yang semakin canggih, menjadikan pencatatan siklus akuntansi pada zaman dahulu yang masih menggunakan sistem manual telah bergeser menggunakan sistem komputer (elektronik). Salah satu aktivitas yang sering dilakukan adalah aktivitas yang berhubungan dengan penerimaan kas. Sistem informasi akuntansi penerimaan kas merupakan bagian penting dalam siklus akuntansi yang digunakan oleh suatu perusahaan sebagai sarana penunjang kegiatan operasional . Sistem penerimaan kas di LAZISMU Sidoarjo melalui hasil wawancara berasal dari tiga sumber kegiatan yaitu penerimaan kas secara langsung, penerimaan kas melalui transfer, dan penerimaan kas melalui penjemputan zakat. penerimaan kas adalah kas yang diterima perusahaan baik yang berupa uang tunai maupun surat-surat berharga yang mempunyai sifat dapat segera digunakan, yang berasal dari transaksi perusahaan mapun penjualan tunai, pelunasan piutang atau transaksi lainnya yang dapat menambah kas perusahaan. subsistem yang membentuk sistem akuntansi penerimaan kas dalam organisasi pengelola zakat adalah prosedur penerimaan kas tunai dan prosedur penerimaan kas melalui trnasfer bank. Hanya saja pada LAZISMU Sidoarjo menambahkan prosedur penerimaan kas melalui penjemputan zakat. Sebagaimana organisasi pengelola zakat pada dasarnya penghimpunan dana zakat merupakan tugas dan tanggung jawab amil zakat seperti dijelaskan dalam Al-Qur'an Surah AtTaubah ayat 103 sebagai berikut:

Artinya: "Ambillah zakat dari sebagian harta mereka, dengan zakat itu kamu membersihkan dan mensucikan mereka dan mendoalah untuk mereka. Sesungguhnya doa kamu itu (menjadi) ketenteraman jiwa bagi mereka. Dan Allah Maha Mendengar lagi Maha Mengetahui."

Ayat diatas menjadi dasar praktik penghimpunan dana zakat, infaq, dan shadaqah LAZISMU Sidoarjo. Sebagai lembaga pengelola zakat sudah menjadi suatu kewajiban bagi mereka untuk menjalankan tugas dan tanggung jawabnya dalam melakukan penghimpunan dana ZIS. Sehingga yang mengeluarkan zakat jiwanya akan merasa tentram, selain itu juga zakat bukan hanya membersihkan dan mensucikan hati manfaat zakat juga dapat dirasakan diri sendiri juga dapat dirasakan oleh orang lain sehingga dapat menolong sesama manusia yang membutuhkan.

Mengingat bahwa kas merupakan aset yang paling lancar dibanding aset lainnya, maka untuk mengamankan penerimaan kas ini diperlukanlah sebuah sistem pengendalian internal yang sangat baik dan ekstra hati-hati. Sistem pengendalian internal kas suatu perusahaan akan berbeda satu dengan lainnya tergantung dari bentuk, jenis, dan sifat perusahaannya. Untuk mendukung dari proses pengendalian tersebut agar berjalan secara efektif, harus memiliki unsur pokok sistem pengendalian. Dari hasil penelitian yang telah diuraikan di atas, dalam prakteknya penerapan sistem informasi akuntansi sangat penting dalam upaya pengendalian penerimaan kas di LAZISMU Sidoarjo. Dari segi struktur organisasi ada bagian yang tidak terisi atau kosong sehingga ada fungsi atau bagian lain bertugas merangkap. dalam menyusun struktur organisasi pemisahan antara setiap fungsi yang ada dan suatu fungsi jangan diberi tanggungjawab penuh melaksanakan semua tahapan kegiatan. Sistem wewenang dan prosedur pencatatan dalam organisasi berdasarkan hasil wawancara dan observasi bahwa sistem wewenang dan prosedur pencatatan oleh LAZISMU Sidoarjo, uraian tugas didukung petunjuk prosedur pelaksanaan tugas yang disertai penjelasan. Sedangkan prosedur pencatatan proses transaksi hanya diotorisasi oleh pihak atau pejabat berwenang dengan bukti yang sah. Kemudian pengendalian internal dilihat dari pelaksanaan kerja yang sehat. LAZISMU Sidoarjo telah melakukan pelaksanaan kerja yang sehat berdasarkan hasil wawancara dan observasi bahwa telah menggunakan formulir atau dokumen bernomor urut cetak agar setiap dokumen dapat dipertanggungjawabkan dan mengurangi terjadinya penipuan. Dalam menangani transaksi suatu transaksi tidak boleh ditangani oleh satu orang saja dari awal hingga akhir. Akan tetapi, berdasarkan hasil wawancara ada fungsi atau bagian di LAZISMU Sidoarjo hanya dilakukan oleh satu orang saja sehingga tidak sesuai dengan teori dimana adanya pemisahan tugas antara individu yang menerima kas, mencatat atau membukukan penerimaan kas, dan yang menyimpan kas. Untuk mengantisipasi adanya kecurangan dalam penerimaan kas seharusnya tidak dilakukan oleh satu orang saja. Harus ada satu orang lagi sebagai saksi. Sebagaimana disebutkan dalam Al-Qur'an surah Al-Baqarah ayat 282 yang berbunyi:

Artinya: “....Dan persaksikanlah dengan dua orang saksi dari orang-orang lelaki (di antaramu). Jika tak ada dua oang lelaki, maka (boleh) seorang lelaki dan dua orang perempuan dari saksi-saksi yang kamu ridhai, supaya jika seorang lupa maka yang seorang mengingatkannya...."

Ayat diatas menjelaskan bahwa pada saat transaksi, maka harus ada dua saksi yang menyaksikan. Oleh karena itu, baik dari petugas penerima kas pada bagian administrasi maupun petugas jungut akan lebih baik jika terdiri dua orang, satu orang yang bertransaksi, dan satu orang sebagai saksi transaksi. Hal ini perlu dilakukan untuk menghindari fitnah dan informasi yang diperoleh oleh bagian administrasi maupun petugas sehingga lebih akurat dan tidak terjadi kesalahan pencatatan karena adanya saksi dalam transaksi tersebut. Agar kepercayaan para muzakki dalam menyalurkan zakatnya ke lembaga amil zakat meningkat, lembaga amil harus mempertanggung jawabkan dana yang terkumpul dengan menerapkan pengendalian internal yang baik. Dalam hal ini, LAZISMU Sidoarjo menyajikan laporan keuangan transparan kepada publik hal ini dibuktikan melalui hasil wawancara. Dalam penerimaan kas penyetoran kas ke bank dilakukan setiap hari dan langsung disetorkan di 
hari kerja bank. Hal ini sesuai dengan teori dimana uang kas hasil penerimaan harus disetor ke bank setiap hari. Dalam mengantisipasi adanya kesalahan pencatatan pada penerimaan kas dilakukan crossceck dan evaluasi melalui rapat, hal ini dibuktikan melalui hasil wawancara dan sesuai dengan teori dengan melakukan pengecekan independen atau verifikasi internal. Pada peneriman kas melalui transfer bank, LAZISMU Sidoarjo menggunakan pemisahan nomor rekening antara infaq atau shadaqah dengan zakat. Hal ini sesuai dengan teori yang umumnya perusahaan tidak hanya memiliki satu rekening bank saja tetapi beberapa rekening bank sekaligus pada saat yang bersamaan. Beberapa rekening ini memang secara khusus dibuka oleh perusahaan dengan tujuan untuk mengakomodir masing-masing keperluan yang berbeda. Penyebab gagalnya pengendalian dikarenakan oleh manfaat dan biaya, persengkolan (kolusi), dan kelemahan manusia. Untuk mengatasi human error dengan diimbangi sumber daya manusia bagian keuangan yang kompeten selain itu juga dalam meningkatkan kompetensi dan keahliannya dilakukan pelatihan.

\section{KESIMPULAN}

Berdasarkan penelitian yang dilakukan untuk melihat bagaimana penerapan sistem informasi akuntansi pada lembaga zakat, infaq, shadaqah dalam upaya peningkatan pengendalian internal pada penerimaan kas. Dengan melihat hasil dari analisis data, maka kesimpulannya sebagai berikut: Pemrosesan data dan informasi di LAZISMU Sidoarjo telah menggunakan sistem dari sentral pusat yaitu ZISKA singkatan dari (Zakat, Infaq, Shadaqah, dan Kemanusiaan). ZISKA merupakan sistem berbasis excel yang diterapkan oleh bagian administrasi dan perkantoran dalam memproses data dan informasi keuangan sehingga mempermudah pekerjaan di bidang keuangan. Kelebihan dari sistem tersebut lebih terperinci. Namun, terdapat kendala seperti gangguan jaringan dan untuk mencegah adanya risiko kehilangan data tersebut dilakukan backup data. Sistem penerimaan kas di LAZISMU Sidoarjo berasal dari Tiga sumber kegiatan yaitu penerimaan kas secara langsung, penerimaan kas melalui transfer, dan penerimaan kas melalui penjemputan zakat. Namun, pada proses transfer adanya pihak yang tidak mencantumkan nama pengirim. Dari segi struktur organisasi ada bagian yang tidak terisi atau kosong sehingga ada fungsi atau bagian lain bertugas merangkap. Untuk mengantisipasi adanya kesalahan pencatatan pada penerimaan kas dilakukannya crossceck dan evaluasi melalui rapat. Selain itu, penggunaan formulir atau dokumen telah bernomor urut tercetak. Laporan keuangan yang transparan kepada publik hanya dipublikasikan pada majalah. Penyetoran kas ke bank dilakukan setiap hari dan langsung disetorkan di hari kerja bank. Unsur pengendalian internal pada penerapan sistem informasi akuntansi ditemukan beberapa kelemahan: Kelemahan pertama, adanya bagian atau fungsi lain yang kosong sehingga ada fungsi atau bagian yang merangkap. Selain itu, pada bagian penerimaan kas dan penjemputan zakat hanya dilakukan oleh satu orang saja. Hal ini akan menimbulkan kecurangan jika tidak adanya saksi. Kelemahan kedua, pada bagian administrasi dan perkantoran mengotorisasi kwitansi dengan tanda tangan dan dibubuhi dengan stempel organisasi. Namun, terkadang adanya ketidaktelitian dari petugas seperti lupa memberikan stempel pada kwitansi pembayaran. Pembuatan flowchart sangat diperlukan agar pihak yang membutuhkan dapat mengetahui dengan mudah sistem yang digunakan oleh LAZISMU Kabupaten Sidoarjo. Melakukan peningkatan performa dan jaringan yang bagus untuk perbaikan agar lebih efektif digunakan.Apabila ada bagian yang kosong atau belum terisi segera merekrut pegawai agar tidak terjadi tugas pada fungsi lain yang merangkap dan Pembuatan flowchart sangat diperlukan agar pihak yang membutuhkan dapat mengetahui dengan mudah sistem yang digunakan oleh LAZISMU Kabupaten Sidoarjo.

\section{REFERENCES}

Amaliah, T. H., Husain, S. P., \& Selviyanti, N. 2019. Pengaruh Penatausahaan Barang Milik Negara Dan Penerapan Sistem Informasi Manajemen Akuntansi Barang Milik Negara Terhadap Kualitas Laporan Keuangan. Jurnal Wawasan Dan Riset Akuntansi. Https://Doi.Org/10.25157/Jwr.V6i2.1907

Aminah, S. 2016. Pengaruh Penerapan Teknologi Informasi Dan Saling Ketergantungan Organisasional Terhadap Penerapan Sistem Informasi Akuntansi Manajemen (Survey Pada Pt.Inti Persero). Universitas Pasundan.

Anto, La Ode, Tamburaka, S., \& Abbas, Andi Adelia. 2020. Penerapan Sistem Informasi Akuntansi Dalam Pengambilan Kebijakan Akuntansi Pemerintah Daerah Kota Kendari. Jurnal Akuntansi Dan Keuangan (Jak).

Astuti, N. M. M. P., \& Dharmadiaksa, I. B. 2014. Pengaruh Efektivitas Penerapan Sistem Informasi Akuntansi, Pemanfaatan Dan Kesesuaian Tugas Pada Kinerja Karyawan. Jurnal Akuntansi Universitas Udayana.

Chairina, F., \& Wehartaty, T. 2019. Pengaruh Penerapan Sistem Informasi Akuntansi Terhadap Kualitas Laporan Keuangan Pada Bpkpd Kota Surabaya. Jurnal Akuntansi Kontemporer. Https://Doi.Org/10.33508/Jako.V11i1.2073

Dewa Made Agung Putra Wiguna, I. B. D. 2016. Pengaruh Penerapan Sistem Informasi Akuntansi Terhadap Kinerja Individual Dengan Budaya Organisasi Sebagai Pemoderasi. E-Jurnal Akuntansi Universitas Udayana.

Dita, M. A., \& Putra, I. W. 2016. Pengaruh Penerapan Sistem Informasi Akuntansi Terhadap Kinerja Karyawan Dengan Integritas Karyawan Sebagai Variabel Pemoderasi. E-Jurnal Akuntansi.

Dr. Wahidmurni, M. P. 2017. Pemaparan Metode Penelitian Kualitatif. Repository Universitas Islam Negeri Maulana Malik Ibrahim Malang.

Fauziah, R. M. 2018. Pengaruh Efektivitas Penerapan Sistem Informasi Akuntansi, Gaya Kepemimpinan, Motivasi Kerja Dan Disiplin Kerja Terhadap Kinerja Karyawan Studi Pada Pd. Bpr Sarimadu Kantor Pusat Bangkinang. Pengaruh Efektivitas Penerapan Sistem Informasi Akuntansi, Gaya Kepemimpinan, Motivasi Kerja Dan Disiplin Kerja Terhadap Kinerja Karyawan Studi Pada Pd. Bpr Sarimadu Kantor Pusat Bangkinang.

Gunawan, I. 2014. Metode Penelitian Kualitatif: Teori Dan Praktik. Jakarta: Bumi Aksara.

Hati, R. P. 2017. Pengaruh Efektifitas Penerapan Sistem Informasi Akuntansi, Pemanfaatan Dan Kesesuaian Tugas Pada Kinerja Pengurus Koperasi (Aktif Dan Terdaftar Di Dinas Koperasi Dan Usaha Mikro). Measurement.

Lexy J. Moleong, D. M. A. 2019. Metodologi Penelitian Kualitatif (Edisi Revisi). Pt. Remaja Rosda Karya. Https://Doi.Org/10.1016/J.Carbpol.2013.02.055

Puji Astuti, N., \& Dharmadiaksa, I. 2014. Pengaruh Efektivitas Penerapan Sistem Informasi Akuntansi, Pemanfaatan Dan Kesesuaian Tugas Dengan Teknologi Informasi Pada Kinerja Karyawan. E-Jurnal Akuntansi.

Rahayu, N. L. S., Sulindawati, N. L. G. E., \& Sinarwa, N. K. 2014. Pengaruh Partisipasi Penyusunan Anggaran, Kualitas Sumber Daya Manusia (SDM), Dan Penerapan Sistem Informasi Akuntansi Terhadap Kinerja Pemerintah Daerah. E-Journal S1 Ak Universitas Pendidikan Ganesha.

Rijali, A. 2019. Analisis Data Kualitatif. Alhadharah: Jurnal Ilmu Dakwah. Https://Doi.Org/10.18592/Alhadharah.V17i33.2374

Sekaran, U., \& Bogie, R. 2017. Metode Penelitian Untuk Bisnis. Jakarta: Salemba Empat.

Sugiyono. 2015. Metode Penelitian Kuantitatif, Kualitatif, Dan R\&D (Cetakan Ke). Bandung: Alfabeta.

Sugiyono. 2016. Memahami Penelitian Kualitatif. Bandung: Alfabeta.

Sujadijaya, T. 2017. Pengaruh Penerapan Sistem Informasi Akuntansi Terhadap Kualitas Laporan Keuangan (Studi Pada Pt Kareta Api Indonesia (Persero) Kota Bandung). Journal Of Chemical Information And Modeling.

Sutra, M. A. A., \& Prabawa, D. K. G. 2020a. Pengaruh Efektivitas, Pemanfaatan Dan Kesesuaian Tugas Penerapan Sistem Informasi Akuntansi Terhadap Kinerja Karyawan Koperasi Di Desa Panjer. Tiers Information Technology Journal.

Suwarsono, S. 2016. Pengantar Penelitian Kualitatif. Hari Studi Dosen Program Studi Pendidikan Matematika. 
Conflict of InterestStatement:Theauthorsdeclare that theresearchwas conducted in the absence of any commercial or financial relationships that could be construed as a potential conflict of interest.

Copyright (C) 2022 and. This is an open-access article distributed under the terms of the Creative Commons Attribution License (CC BY). The use, distribution or reproduction in other forums is permitted, provided the original author(s) and the copyright owner(s) are credited and that the original publication in this journal is cited, in accordance with accepted academic practice. No use, distribution or reproduction is permitted which does not comply with these terms. 


\section{LIST OF TABLES}

1. Proses Coding...... 
TABLE 1 | Proses Coding

\begin{tabular}{cc} 
Coding & Tema atau Pola yang sama \\
\hline 1 & $\begin{array}{l}\text { penerapan sistem informasi akuntansi pada lembaga zakat, } \\
\text { infaq, dan shadaqah dalam upaya peningkatan pengendalian }\end{array}$
\end{tabular}

internal pada penerimaan kas 


\section{LIST OF FIGURES}

1 Flowchart Penerimaan Kas 
Figure 1 | Flowchart Penerimaan Kas Tunai

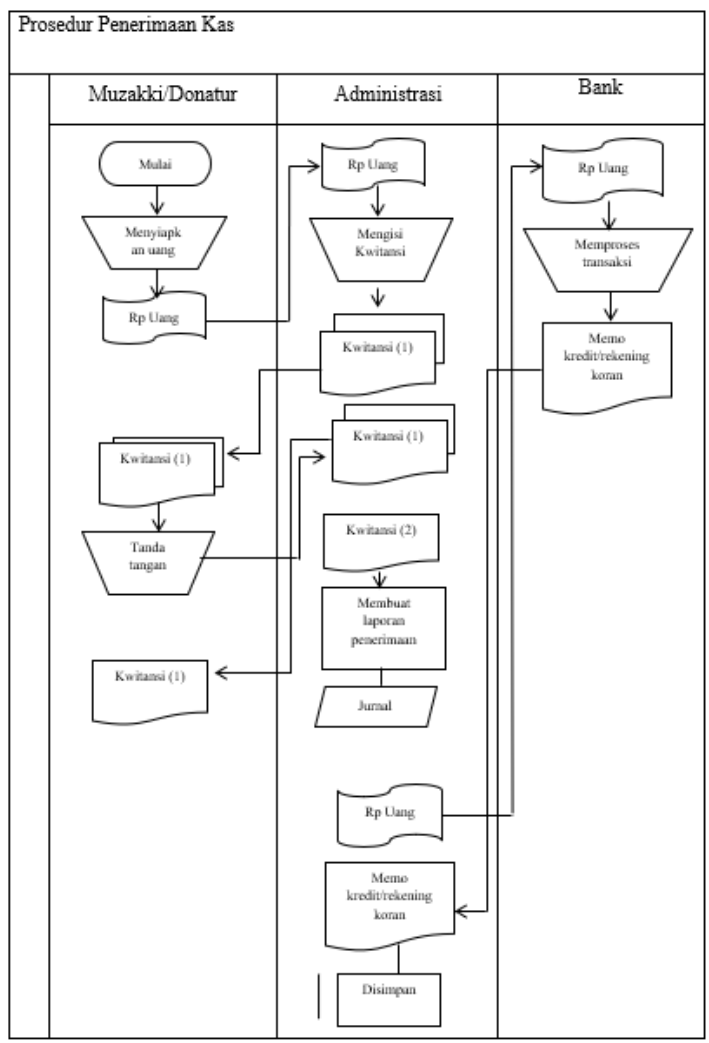

